\title{
Metabotropic Glutamate Receptor 2
}

National Cancer Institute

\section{Source}

National Cancer Institute. Metabotropic Glutamate Receptor 2. NCI Thesaurus. Code C114528.

Metabotropic glutamate receptor $2(872 \mathrm{aa}, \sim 96 \mathrm{kDa}$ ) is encoded by the human GRM2 gene. This protein plays a role in neurotransmitter-dependent signaling. 